\title{
Imatinib promotes apoptosis of giant cell tumor cells by targeting microRNA-30a-mediated runt-related transcription factor 2
}

\author{
YUXIANG LIAO, GUOHUA LV, BING WANG, LEI KUANG and XIAOBIN WANG \\ Department of Spinal Surgery, The Second Xiangya Hospital, Central South University, Changsha, Hunan 410011, P.R. China
}

Received November 21, 2014; Accepted September 25, 2015

DOI: $10.3892 / \mathrm{mmr} .2015 .4722$

\begin{abstract}
Giant cell tumor (GCT) is an aggressive type of bone tumor consisting of multinucleated osteoclast-like giant cells. Imatinib is a selective inhibitor for certain type III tyrosine kinase receptor family members with a variety of beneficial effects. The purpose of the present study was to determine the therapeutic potential and underlying mechanism of imatinib against GCT. In the present study, cell viability and apoptosis in GCT were analyzed using the MTT assay, flow cytometry and DAPI staining assay. Caspase-3 and -9 activity in GCT cells were analyzed with colorimetric assay kits. In addition, the expression levels of runt-related transcription factor 2 (RunX2) protein and microRNA-30a (miR-30a) in GCT cells were detected using western blotting and quantitative polymerase chain reaction, respectively. Results from the present study demonstrated that imatinib treatment inhibited cell viability, increased cell apoptosis, and significantly promoted caspase- 3 and -9 activity in GCT. In addition, imatinib treatment decreased the RunX2 protein expression level. Notably, imatinib was demonstrated to increase miR-30a expression. However, upregulation of miR-30a expression reduced the RunX2 protein expression level, and downregulation of miR-30a expression reversed the anticancer effect of imatinib on GCT, increasing the expression level of RunX2 protein in GCT. The results of the present study indicate that imatinib promotes apoptosis of GCT cells by targeting the miR-30a-mediated RunX2 signaling pathway.
\end{abstract}

\section{Introduction}

Giant cell tumor (GCT) is a disease, which is characterized by locally aggressive behavior, and designated as an osteoclastoma due to the multi-nucleated, osteoclast-like giant cells observed morphologically and histologically $(1,2)$. GCT

Correspondence to: Professor Guohua Lv, Department of Spinal Surgery, The Second Xiangya Hospital, Central South University, 139 Renmin Road, Changsha, Hunan 410011, P.R. China

E-mail: guohualvdl@163.com

Key words: giant cell tumor, imatinib, runt-related transcription factor 2, microRNA-30a accounts for $11 \%$ of all bone tumors in China, with the second highest incidence after osteochondroma (3).

Runt-related transcription factor 2 (RunX2), also termed core-binding factor $\alpha 1$, belongs to the transcription factors of the Runt domain gene family. The expression of RunX2 is regulated by multiple growth factors and hormones involved in bone cell differentiation $(3,4)$. Mak et al $(5)$ reported that RunX2 is crucial in GCT stromal cells through upregulation of matrix metalloproteinase-13. Singh et al (6) confirmed the significant role of fibroblast growth factor receptor-2 signaling in osteoblastic differentiation in GCT stromal cells via inhibition of the extracellular signal-regulated kinases 1 and 2 (ERK1/2) signaling pathway.

MicroRNAs (miRs) are widely distributed in a variety of organisms and regulate gene expression. They are involved in the proliferation, differentiation and apoptosis of cells, in addition to other important cell regulatory activities (7). The miR-30a genes exist in the genome in a variety of forms. Previous studies have demonstrated that miRs may produce similar effects to oncogenes or tumor suppressor genes and various types of miR-30a are expressed abnormally in GCT tissues (8-10). Furthermore, Huang et al (11) suggested that miR-30a inhibited GCT of bone by targeting RunX2.

Imatinib is a selective inhibitor of certain type III tyrosine kinase receptor family members, including CD117, platelet-derived growth factor receptor and the ABL family of tyrosine kinases, which leads to inhibition of BCR-ABL protein expression (12). Studies have demonstrated that imatinib competes with ATP in binding to the nucleotide-binding site catalyzed by the tyrosine kinase (13-15). The catalytic activity of the kinase, therefore, cannot occur and the phosphorylated substrate cannot interact with downstream effector molecules, which leads to the inhibition of cell proliferation and induces apoptosis (16). In the present study, the anticancer effect of imatinib on GCT cell apoptosis was evaluated and the signaling cascades that may mediate this effect were investigated. The findings of the present study indicate that imatinib regulates apoptosis of GCT cells by suppression of RunX2 and activation of miR-30a, indicating that imatinib may serve as an important novel molecular target for the treatment of GCT.

\section{Materials and methods}

Reagents. The chemical structure of imatinib (Sigma-Aldrich, St. Louis, MO, USA; purity, $\geq 98 \%$ ) is presented in Fig. 1. 
Hyclone RPMI-1640 was obtained from GE Healthcare Life Sciences (Logan, UT, USA) and Gibco fetal bovine serum (FBS) was obtained from Thermo Fisher Scientific, Inc. (Waltham, MA, USA). A Vybrant ${ }^{\circledR}$ MTT Cell Proliferation Assay kit was purchased from Molecular Probes (Thermo Fisher Scientific, Inc.), and Caspase-3 and -9 Colorimetric Assay kits were purchased from Beyotime Institute of Biotechnology (Jiangsu, China). A Molecular Probes Annexin V-FITC/PI Apoptosis Detection kit was obtained from Thermo Fisher Scientific, Inc. A BCA Protein Assay kit was obtained from Beyotime Institute of Biotechnology (Nanjing, China). TRIzol ${ }^{\circledR}$ and an miRNA qRT-PCR kit were obtained from Invitrogen (Thermo Fisher Scientific, Inc.).

Ethics statement, tissue samples and cell lines. The present study was approved by the regional ethics committee of Second Xiangya Hospital, Central South University (Changsha, China) and written informed consent was obtained from the patients. GCT samples were collected from male patients (age, $58 \pm 5$ years) at the Second Xiangya Hospital, Central South University between October 2013 and January 2014. The tumor tissue samples were maintained in RPMI-1640 containing $10 \%$ FBS, $100 \mathrm{U} / \mathrm{ml}$ penicillin and $100 \mathrm{mg} / \mathrm{ml}$ streptomycin (both Amresco, LLC, Solon, OH, USA). The small sections of tissue $(500 \mathrm{mg}$ ) and the resultant cell suspension were transferred to $25-\mathrm{cm}^{2}$ flasks, which were incubated at $37^{\circ} \mathrm{C}$ in a humidified atmosphere of $5 \% \mathrm{CO}_{2}$. Half of the culture medium was replaced with fresh complete medium every 2 days. Primary cultures were subcultured and stored in liquid nitrogen until reaching confluence. The purified GCT samples then underwent bisphosphonate treatment (Amresco, LLC) and evaluation (2). GCT cells ( $2.5 \times 10^{5}$ cells/well) were cultured in complete medium and treated with imatinib at different concentrations $(0,0.625,1.25,2.5,5$ and $10 \mu \mathrm{M})$ for 3 days.

Cell viability assay. GCT cells $\left(2.0 \times 10^{4}\right.$ cells/well) were seeded in 96-well plates and cultured with imatinib $(0$, $0.625,1.25,2.5,5$ and $10 \mu \mathrm{M})$ at a temperature of $37^{\circ} \mathrm{C}$ in a humidified atmosphere of $5 \% \mathrm{CO}_{2}$ for $0,1,2$ and 3 days. The cell viability was determined using the MTT assay. MTT $(10 \mu \mathrm{l})$ was added to each well and incubated for $4 \mathrm{~h}$ at $37^{\circ} \mathrm{C}$ in a humidified atmosphere of $5 \% \mathrm{CO}_{2}$. The culture medium was removed and $150 \mu \mathrm{l}$ dimethyl sulfoxide (Invitrogen; Thermo Fisher Scientific, Inc.) was added to each well and incubated for $20 \mathrm{~min}$ at room temperature whilst being agitated. The absorbance was determined with an ELISA reader (Infinite ${ }^{\circledR} 200$ PRO; Tecan, Männedorf, Switzerland) at a wavelength of $570 \mathrm{~nm}$.

Flow cytometric analysis of GCT cell apoptosis. GCT cells $\left(2.5 \times 10^{5}\right.$ cells/well $)$ were seeded in 6-well plates and cultured with imatinib $(1.25,2.5$ and $5 \mu \mathrm{M})$ for $48 \mathrm{~h}$. GCT cells were washed twice with ice-cold phosphate-buffered saline (Beyotime Institute of Biotechnology). The cells were stained with $10 \mu l$ Annexin V-fluorescein isothiocyanate and incubated for $10 \mathrm{~min}$ in the dark. Next, $10 \mu \mathrm{l}$ propidium iodide was added to the cells and cell apoptosis was immediately detected using an EPICS ${ }^{\circledR}$ ALTRA $^{\text {TM }}$ flow cytometer (Beckman Coulter, Inc., Brea, CA, USA).

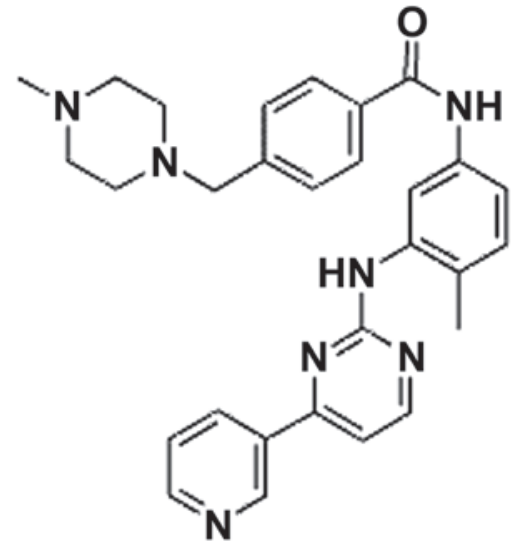

Figure 1. Chemical structure of imatinib.

Detection of caspase-3 and -9 activity levels. GCT cells $\left(2.5 \times 10^{5}\right.$ cells/well) were seeded in 6-well plates and cultured with imatinib $(1.25,2.5$ and $5 \mu \mathrm{M})$ for $48 \mathrm{~h}$. The caspase-3 and -9 activity level was detected via fluorescence at a wavelength of $405 \mathrm{~nm}$ using the caspase- 3 and -9 colorimetric assay kits.

Western blotting for RunX2 protein expression levels. GCT cells $\left(2.5 \times 10^{5}\right.$ cells/well $)$ were seeded in 6 -well plates and cultured with imatinib $(1.25,2.5$ and $5 \mu \mathrm{M})$ for $48 \mathrm{~h}$. The cells were incubated with ice-cold lysis buffer (Beyotime Institue of Biotechnology) and maintained for $30 \mathrm{~min}$ on ice. The suspension was centrifuged at $12,000 \mathrm{x}$ g for $10 \mathrm{~min}$ at $4^{\circ} \mathrm{C}$. The liquid supernatant was collected to measure the protein concentration using the BCA protein assay. Proteins were separated using $12 \%$ sodium dodecyl sulfate-polyacrylamide gels (Beyotime Institute of Biotechnology) with Coomassie Brilliant Blue (Sangon Biotech Co., Ltd., Shanghai, China) and transferred to polyvinylidene fluoride membranes $(0.22 \mathrm{~mm}$; EMD Millipore, Billerica, MA, USA). The blotting membrane was treated with Tris-buffered saline (TBS) containing 5\% non-fat milk to block non-specific binding sites. The membranes were then incubated with mouse monoclonal RunX2 (1:1,000; cat. no. sc-390715; Santa Cruz Biotechnology, Inc., Dallas, TX, USA) and rabbit polyclonal anti- $\beta$-actin (1:500; cat. no. D110007; Sangon Biotech) antibodies overnight at $4^{\circ} \mathrm{C}$. The membrane was washed twice with TBS with Tween-20 for $2 \mathrm{~h}$ and incubated with monoclonal anti-mouse immunoglobulin G (1:1,000; cat. no. sc-51997; Santa Cruz Biotechnology, Inc.) conjugated with horseradish peroxidase for $2 \mathrm{~h}$. Enhanced chemiluminescence [GE Healthcare Life Sciences] was conducted to detect the protein expression level.

Quantitative polymerase chain reaction $(q P C R)$ analysis of miR-30a expression levels. GCT cells $\left(2.5 \times 10^{5}\right.$ cells/well $)$ were seeded in 6-well plates and cultured with imatinib $(1.25,2.5$ and $5 \mu \mathrm{M}$ ) for $48 \mathrm{~h}$. Total RNA was extracted from the cells using TRIzol ${ }^{\circledR}$ according to the manufacturer's instructions. The expression of miR-30a was detected using a Bulge-Loop ${ }^{\circledR}$ miRNA qRT-PCR kit (Sharp Bo Biological Technology Co., Ltd., Guangzou, China) and observed by qPCR. The primers used were as follows: Forward, 5'-GCAGTAAGTCACTTG CATGATTGT-3' and revers, 5'-CGCTTGAAGCACTGTCTT 
A 120
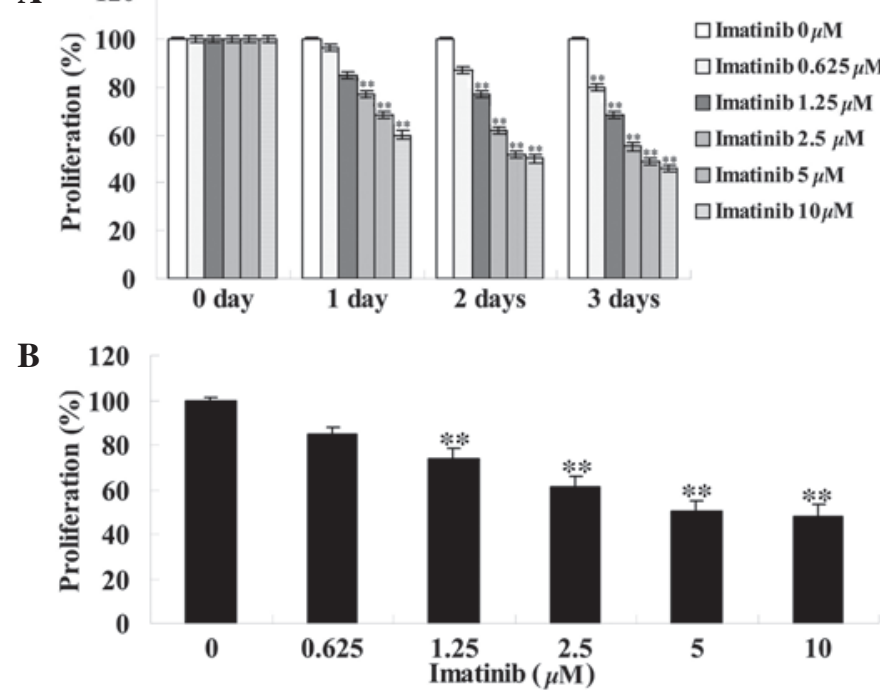

Figure 2. Imatinib inhibits the proliferation of GCT. (A) Imatinib at doses between 0.625 and $10 \mu \mathrm{M}$ inhibited GCT proliferation. (B) Proliferation of GCT was dose-dependently inhibited following 2 days of imatinib treatment. ${ }^{* *} \mathrm{P}<0.01$ vs. the $0 \mu \mathrm{M}$ imatinib-treated group. GCT, giant cell tumor.

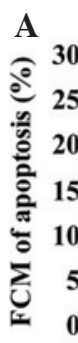

B
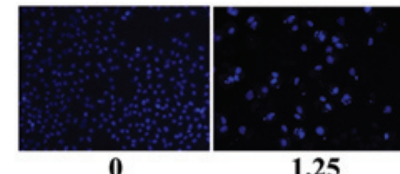

1.25
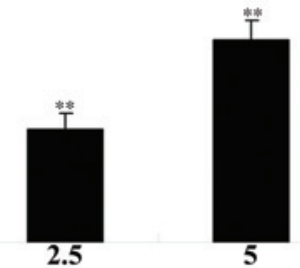

$\operatorname{Imatinib}(\mu \mathbf{M})$

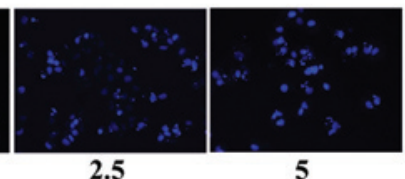

Figure 3. Imatinib induces GCT cell apoptosis. Imatinib induces cellular apoptosis of GCT, which was evaluated using (A) FCM and (B) DAPI staining assay (magnification, $\mathrm{x} 200$ ). ${ }^{* *} \mathrm{P}<0.01 \mathrm{vs}$. the $0 \mu \mathrm{M}$ imatinib-treated group. FCM, flow cytometry; GCT, giant cell tumor.

ATTTGT-3' for miR-30a; and forward, 5'-GTTGACATCCGT AAAGACC-3' and reverse, 5'-GGAGCCAGGGCAGTAA-3' for U6.

Transfection of miR-30a and anti-miR-30a. The miR-30a precursor and anti-miR-30a (Ambion; Thermo Fisher Scientific, Inc.) were synthesized by Sangon Biotech Co., Ltd. and transfected using Invitrogen Lipofectamine 2000 (Thermo Fisher Scientific, Inc.) at a final concentration of $50 \mathrm{nM}$. GCT cells $\left(2.5 \times 10^{5}\right.$ cells/well $)$ were seeded in 6 -well plates for $6 \mathrm{~h}$. The transfection media was then replaced with complete media without antibiotics in a humidified atmosphere at $37^{\circ} \mathrm{C}$ with $5 \% \mathrm{CO}_{2}$ for $18 \mathrm{~h}$.

Statistical analysis. Statistical analysis was performed with SPSS software version 17.0 (SPSS, Inc., Chicago, IL, USA). All experiments were performed at least three times and

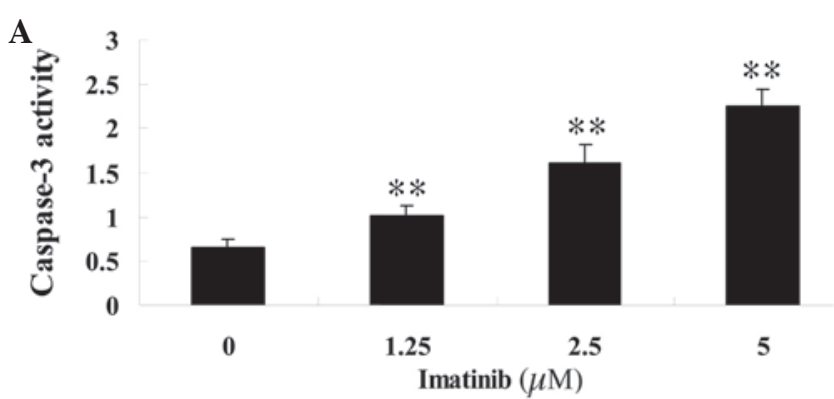

B

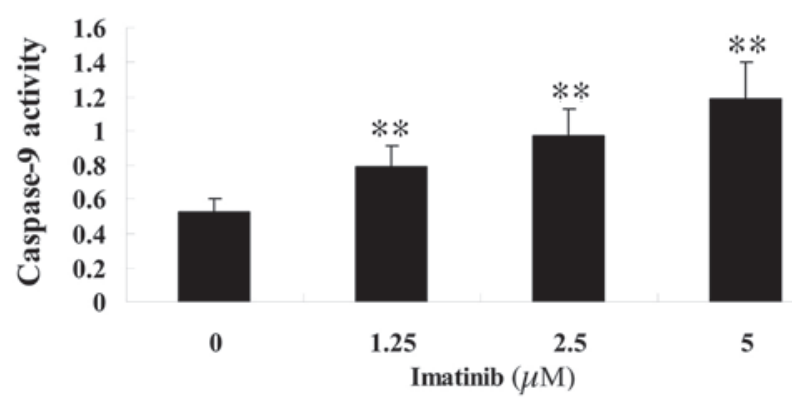

Figure 4. Imatinib induces (A) caspase-3 and (B) caspase-9 activities in giant cell tumor cells. ${ }^{* *} \mathrm{P}<0.01$ vs. the $0 \mu \mathrm{M}$ imatinib-treated group.

data are presented as means \pm standard deviation. Data were analyzed using Student's t-test and $\mathrm{P}<0.05$ was considered to indicate a statistically significant difference.

\section{Results}

Imatinib inhibited cell viability of GCT. To assess the effect of imatinib on cell viability, different concentrations $(0,0.625,1.25$, $2.5,5$ and $10 \mu \mathrm{M})$ of imatinib were incubated with GCT cells for $0,1,2$ and 3 days subsequent to which an MTT assay was performed. As indicated in Fig. 2, imatinib inhibited the viability of GCT cells in a dose- and time-dependent manner. Compared with the control group, the viability of GCT cells significantly 
A

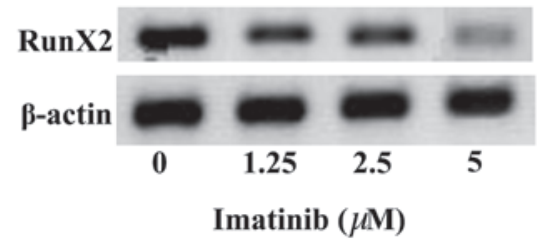

B

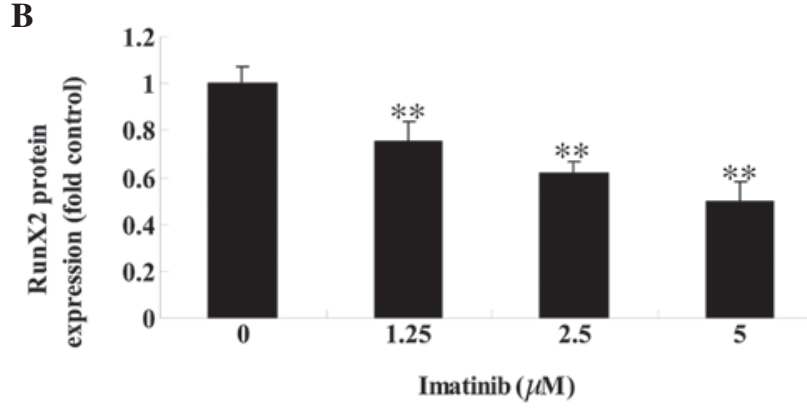

Figure 5. Imatinib inhibits RunX2 protein expression levels in giant cell tumor cells. The effect of imatinib on RunX2 was observed by (A) western blotting and (B) statistical analysis of RunX2 protein expression levels were performed. ${ }^{* *} \mathrm{P}<0.01$ vs. the $0 \mu \mathrm{M}$ imatinib-treated group. RunX2, runt-related transcription factor 2 .

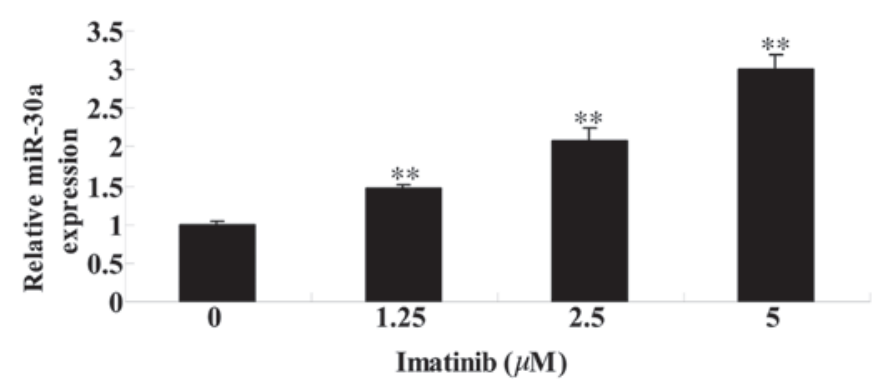

Figure 6. Imatinib activates miR-30a expression in giant cell tumor cells. ${ }^{* *} \mathrm{P}<0.01$ vs. the $0 \mu \mathrm{M}$ imatinib-treated group. miRNA, microRNA.

A

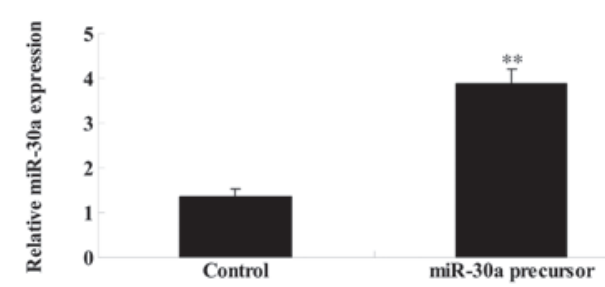

B

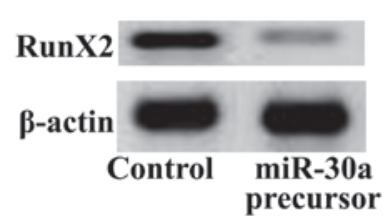

Figure 7. Transfection of an miR-30a plasmid (A) promoted miR-30a expression and inhibited RunX2 expression in giant cell tumor cells. (B) Western blot analysis demonstrating inhibited RunX2 protein expression. ${ }^{* *} \mathrm{P}<0.01$ vs. the $0 \mu \mathrm{M}$ imatinib-treated (control) group. RunX2, runt-related transcription factor 2; miRNA, microRNA.

decreased in a dose-dependent manner following two days of treatment with 1.25, 2.5,5 and $10 \mu \mathrm{M}$ imatinib ( $\mathrm{P}<0.01$; Fig. 2B).
A

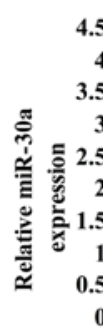

B
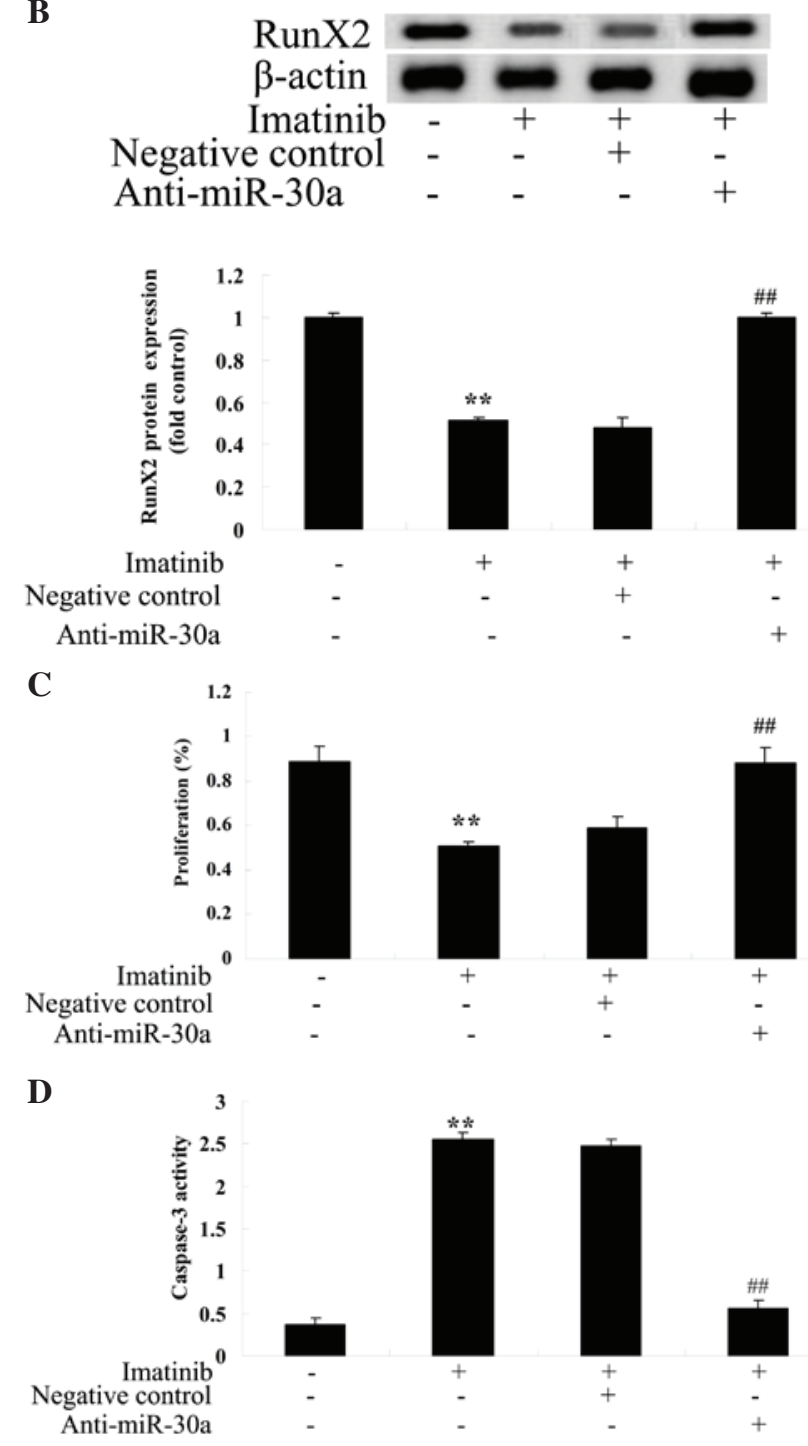

Figure 8. Anti-miR-30a reverses the effect of imatinib on GCT cells. GCT cells were treated with $2.5 \mu \mathrm{M}$ imatinib for 2 days. Anti-miR-30a significantly (A) reduced the expression levels of miR-30a in GCT cells, (B) increased RunX2 protein expression levels in GCT cells, (C) promoted GCT cell proliferation and (D) inhibited caspase-3 activity. ${ }^{* *} \mathrm{P}<0.01$ vs. the $0 \mu \mathrm{M}$ control group and ${ }^{\# \#} \mathrm{P}<0.01$ vs. the imatinib-treated group transfected with negative control. GCT, giant cell tumor; RunX2, runt-related transcription factor 2; miRNA, microRNA.

Imatinib induces cell apoptosis of GCT. Flow cytometry and DAPI staining were used to investigate the effects of imatinib on GCT apoptosis. As demonstrated in Fig. 3A, imatinib treatment $(1.25,2.5$ or $5 \mu \mathrm{M})$ induced cell apoptosis of GCT at 2 days, when compared with the control group. As presented in Fig. 3B, the DAPI dye stained the morphologically normal 
nuclei blue. Morphologic analysis of apoptotic cells demonstrated shrunken and fragmented nuclei, as well as condensed chromatin while the nuclei of normal cells were round, sharp-edged and uniformly stained (Fig. 3B). GCT cell apoptosis was increased in the imatinib-treated $(1.25,2.5$ or $5 \mu \mathrm{M})$ group at 2 days when compared with that of the control group (Fig. 3B).

Imatinib induces caspase-3 and -9 activity of GCT cells. To determine the effect of imatinib on the activity of caspase-3 and -9 , varying concentrations $(1.25,2.5$ and $5 \mu \mathrm{M})$ of imatinib were incubated with GCT cells for 2 days and assayed with colorimetric kits. Following treatment, the activity of caspase-3 and -9 in the GCT cells was significantly increased compared with that of the control group (Fig. 4).

Imatinib downregulates RunX2 protein expression in GCT. To determine the effect of imatinib on RunX2 protein expression levels in GCT cells, western blot analysis was performed. The RunX2 protein expression level in GCT cells was reduced in a dose-dependent manner following 2 days of treatment with 1.25, 2.5 and $5 \mu \mathrm{M}$ imatinib ( $\mathrm{P}<0.01$; Fig. 5).

Imatinib activates miR-30a expression in GCT cells. To further investigate the effect of imatinib on miR-30a in GCT cels, the miR-30a expression level was analyzed using qPCR. Compared with the control group, the level of miR-30a expression was significantly increased following 2 days of imatinib treatment at concentrations of $1.25,2.5$ and $5 \mu \mathrm{M}(\mathrm{P}<0.01$; Fig. 6).

Overexpression of $m i R-30 a$ inhibits RunX2 expression of GCT cells. To investigate the mechanism underlying the effect of imatinib on GCT apoptosis, an miR-30a plasmid was transfected into the GCT cells. The miR-30a plasmid markedly upregulated the expression of miR-30a in the GCT cells (Fig. 7A), which reduced the level of RunX2 protein expression (Fig. 7B).

Anti-miR-30a reverses the effect of imatinib on GCT cells. To further investigate the potential association between miR-30a expression and the effect of imatinib on GCT cells, analysis of the effect of imatinib on GCT was conducted following transfection of an anti-miR-30a plasmid into GCT cells. The anti-miR-30a plasmid reduced the expression of miR-30a (Fig. 8A) and increased RunX2 protein expression (Fig. 8B). Furthermore, the anti-miR-30a plasmid increased cell viability (Fig. 8C) and reduced caspase-3 activity in GCT cells (Fig. 8D).

\section{Discussion}

GCT is a locally aggressive bone tumor, with characteristic postoperative recurrence of $\leq 42 \%$ (17). GCT contains fibroblast-like, spindle-shaped stromal cells, and multinucleated giant cells, which exhibit resorption activity that is similar to osteoclasts (18). The current study presented evidence that imatinib inhibited cell viability and promoted cell apoptosis in GCT in a dose-dependent manner. Maass et al (19) reported that imatinib cured patients with metastatic breast cancer, de Melo Campos et al (20) suggested that imatinib induced apoptosis of neoplastic mast cells and Halperin et al (21) reported that imatinib inhibited the viability of advanced endocrine cancer. In the present study, exposure to imatinib significantly increased the activity of caspase- 3 and -9 in GCT cells. Zhang et al (22) suggested that imatinib increased the levels of cleaved caspase- 3 and -9 in vitro and in vivo, and Gamas et al (23) demonstrated that imatinib mediated apoptosis of myelogenous leukemia cells by mediating caspase- 3 activation.

ERK is an important signaling pathway for integrin signaling to the nucleus (24). Signaling molecules activate integrin, which promotes RunX2-dependent transcription and, using U0126, rapidly inhibits ERK phosphorylation and activation of the osteocalcin gene, upon which ERK is dependent. In a previous study, ERK1-overexpressing transfected cells were produced in which ERK1 elevated the level of osteocalcin mRNA and significantly increased the phosphorylation of RunX2, indicating that the phosphorylation cascade of mitogen-activated protein kinase (MAPK) may regulate the activity of RunX2 (25). Following integration of the integrin ligand with the integrin on the surface of osteoblasts, MAPK signaling pathways are activated to transfer signals to the nucleus, promoting the expression of RunX2 and RunX2 protein phosphorylation $(26,27)$. Activated RunX2 promotes the differentiation of osteoblasts by activating marker genes of osteoblast cells (including osteocalcin) (28). In the present study, the RunX2 protein level in GCT cells was significantly decreased in a dose-dependent manner following two days of imatinib treatment. Jönsson et al (29) reported that imatinib inhibited the proliferation of human mesenchymal stem cells via modulation of RunX2 expression levels and Tibullo et al (30) demonstrated that imatinib potentially favored osteoblastogenesis by mRNA expression of RunX2.

miRs are closely associated with various types of cancer. Previous studies have demonstrated that breast (31), ovarian (32), gastric (33) and lung (34) cancer all demonstrate abnormal expression of miRs (35). miRNA-30a is closely associated with the occurrence and development of GCT, as well as other types of tumor (such as breast and renal cell cancers) $(36,37)$. The study of miRs is important for early clinical diagnosis, treatment and prognosis of GCT. Specific miR-30a expression profiling of GCT, and detection and monitoring of miR-30a in the peripheral blood may serve as an effective marker for GCT diagnosis, screening and to produce effective, novel treatments (38). Data obtained in the present study suggest that imatinib treatment significantly increased the miR-30a expression in GCT cells. Yu et al (39) demonstrated that the administration of imatinib against human chronic myeloid leukemia cells functioned by targeting miR-30a-mediated processes. Furthermore, Yu et al (40) reported that imatinib promoted autophagy in response to cancer therapy via miR-30a-mediated processes. In the present study, overexpression of miR-30a was identified to inhibit RunX2 protein expression in GCT cells. Thus, downregulation of miR-30a may reverse the anticancer effect of imatinib and increase the level of RunX2 protein expression in GCT cells. Recent studies reported that miR-30a inhibited osteolysis by targeting miR-30a-mediated processes in GCTs of the bone $(11,41)$. 
In conclusion, the present study demonstrated that the anticancer effect of imatinib increases apoptosis of GCT cells by downregulating RunX2 protein expression and upregulating the expression of miR-30a. These data indicate that there may be potential benefits of administering imatinib in clinical practice in the future.

\section{References}

1. Wang T, Hou Y, Ding X, Song B, Wang F and Hou W: Overexpression, purification, molecular characterization and pharmacological evaluation for anticancer activity of ribosomal protein S23 from the giant panda (Ailuropoda melanoleuca). Mol Med Rep 7: 1875-1882, 2013.

2. Yang T, Zheng XF, Li M, Lin X and Yin QS: Stimulation of osteogenic differentiation in stromal cells of giant cell tumour of bone by zoledronic acid. Asian Pac J Cancer Prev 14: 5379-5383, 2013.

3. Jiang N, Qin CH, Tan CX, Wen SF, Ma YF, Dong F, Diao XC, Zhang $\mathrm{P}$ and $\mathrm{Yu} \mathrm{B}$ : A retrospective analysis of 140 patients with giant cell tumor in the extremity: a multicenter study based on four hospitals in South China. Cancer Epidemiol 37: 294-299, 2013.

4. Komori T: Mechanism of transcriptional regulation by Runx 2 in osteoblasts. Clin Calcium 16: 801-807, 2006 (In Japanese).

5. Phimphilai M, Zhao Z, Boules H, Roca H and Franceschi RT: BMP signaling is required for RUNX2-dependent induction of the osteoblast phenotype. J Bone Miner Res 21: 637-646, 2006.

6. Mak IW, Cowan RW, Popovic S, Colterjohn N, Singh G and Ghert M: Upregulation of MMP-13 via Runx2 in the stromal cell of Giant Cell Tumor of bone. Bone 45: 377-386, 2009.

7. Singh S, Singh M, Mak IW, Turcotte R and Ghert M: Investigation of FGFR2-IIIC signaling via FGF-2 ligand for advancing GCT stromal cell differentiation. PLoS One 7: e46769, 2012.

8. Kumarswamy R, Mudduluru G, Ceppi P, Muppala S, Kozlowski M, Niklinski J, Papotti $M$ and Allgayer $\mathrm{H}$ : MicroRNA-30a inhibits epithelial-to-mesenchymal transition by targeting Snail and is downregulated in non-small cell lung cancer. Int J Cancer 130: 2044-2053, 2012.

9. Liu J, Shi W, Wu C, Ju J and Jiang J: miR-181b as a key regulator of the oncogenic process and its clinical implications in cancer (Review). Biomed Rep 2: 7-11, 2014.

10. Zou Z, Wu L, Ding H, Wang Y, Zhang Y, Chen X, Chen X, Zhang CY, Zhang Q and Zen K: MicroRNA-30a sensitizes tumor cells to cis-platinum via suppressing beclin 1-mediated autophagy. J Biol Chem 287: 4148-4156, 2012.

11. Huang Q, Jiang Z, Meng T, Yin H, Wang J, Wan W, Cheng M, Yan W, Liu T, Song D, et al: MiR-30a inhibits osteolysis by targeting RunX2 in giant cell tumor of bone. Biochem Biophys Res Commun 453: 160-165, 2014.

12. Roth DB, Akbari S and Rothstein A: Macular ischemia associated with imatinib mesylate therapy for chronic myeloid leukemia. Retin Cases Brief Rep 3: 161-164, 2009.

13. Weisberg E, Deng X, Choi HG, Barrett R, Adamia S, Ray A, Moreno D, Kung AL, Gray N and Griffin JD: Beneficial effects of combining a type II ATP competitive inhibitor with an allosteric competitive inhibitor of BCR-ABL for the treatment of imatinib-sensitive and imatinib-resistant CML. Leukemia 24: 1375-1378, 2010.

14. Dohse M, Scharenberg C, Shukla S, et al: Comparison of ATP-binding cassette transporter interactions with the tyrosine kinase inhibitors imatinib, nilotinib, and dasatinib. Drug Metab Dispos 38: 1371-1380, 2010.

15. Sarszegi Z1, Bognar E, Gaszner B, Kónyi A, Gallyas F Jr, Sumegi B and Berente Z: BGP-15, a PARP-inhibitor, prevents imatinib-induced cardiotoxicity by activating Akt and suppressing JNK and p38 MAP kinases. Mol Cell Biochem 365: 129-137, 2012.

16. Grunwald L, Mehta S, Hogarty MD and Liu GT: Chronic myelogenous leukemia and retinopathy treated with imatinib. Retin Cases Brief Rep 5: 366-368, 2011.

17. Park YS, Lee JK, Baek SW and Park CK: The rare case of giant cell tumor occuring in the axial skeleton after 15 years of follow-up: Case report. Oncol Lett 2: 1323-1326, 2011.

18. Fu S, Bai R, Zhao Z, Zhang Z, Zhang G, Wang Y, Wang Y, Jiang D and Zhu D: Overexpression of hypoxia-inducible factor- $1 \alpha$ and vascular endothelial growth factor in sacral giant cell tumors and the correlation with tumor microvessel density. Exp Ther Med 8: 1453-1458, 2014.
19. Maass N, Schem C, Bauerschlag DO, Tiemann K, Schaefer FW, Hanson S, Muth M, Baier M, Weigel MT, Wenners AS, et al: Final safety and efficacy analysis of a phase I/II trial with imatinib and vinorelbine for patients with metastatic breast cancer. Oncology 87: 300-310, 2014.

20. de Melo Campos P, Machado-Neto JA, Scopim-Ribeiro R, Visconte V, Tabarroki A, Duarte AS, Barra FF, Vassalo J, Rogers HJ, Lorand-Metze I, et al: Familial systemic mastocytosis with germline KIT K509I mutation is sensitive to treatment with imatinib, dasatinib and PKC412. Leuk Res 38: 1245-1251, 2014.

21. Halperin DM, Phan AT, Hoff AO, Aaron M, Yao JC and Hoff PM: A phase I study of imatinib, dacarbazine, and capecitabine in advanced endocrine cancers. BMC Cancer 14: 561, 2014.

22. Zhang YF, Xu GB, Gan YC, Xu XH and Xu RZ: Inhibitory effect of 4-chlorobenzoyl berbamine on imatinib-resistant K562 cells in vitro and in vivo. Nan Fang Yi Ke Da Xue Xue Bao 31: 1997-2001, 2011 (In Chinese).

23. Gamas P, Marchetti S, Puissant A, Grosso S, Jacquel A, Colosetti P, Pasquet JM, Mahon FX, Cassuto JP and Auberger P: Inhibition of imatinib-mediated apoptosis by the caspase-cleaved form of the tyrosine kinase Lyn in chronic myelogenous leukemia cells. Leukemia 23: 1500-1506, 2009.

24. Tatematsu T, Sasaki H, Shimizu S, Okuda K, Shitara M, Hikosaka Y, Moriyama S, Yano M, Brown J and Fujii Y: Investigation of neurotrophic tyrosine kinase receptor 1 fusions and neurotrophic tyrosine kinase receptor family expression in non-small-cell lung cancer and sensitivity to AZD7451. Mol Clin Oncol 2: 725-730, 2014.

25. Xiao ZS, Hjelmeland AB and Quarles LD: Selective deficiency of the bone-related Runx2-II unexpectedly preserves osteoblast-mediated skeletogenesis. J Biol Chem 279: 20307-20313, 2004.

26. Hu N, Feng C, Jiang Y, Miao Q and Liu H: Regulative effect of mir-205 on osteogenic differentiation of bone mesenchymal stem cells (BMSCs): Possible role of SATB2/Runx2 and ERK/MAPK pathway. Int J Mol Sci 16: 10491-10506, 2015.

27. Huang RL, Yuan Y, Tu J, Zou GM and Li Q: Opposing TNF- $\alpha /$ IL-1 $\beta$ - and BMP-2-activated MAPK signaling pathways converge on Runx 2 to regulate BMP-2-induced osteoblastic differentiation. Cell Death Dis 5: e1187, 2014.

28. Glynn ER, Londono AS, Zinn SA, Hoagland TA and Govoni KE: Culture conditions for equine bone marrow mesenchymal stem cells and expression of key transcription factors during their differentiation into osteoblasts. J Anim Sci Biotechnol 4: 40, 2013.

29. Jönsson S, Hjorth-Hansen H, Olsson B, Wadenvik H, Sundan A and Standal T: Imatinib inhibits proliferation of human mesenchymal stem cells and promotes early but not late osteoblast differentiation in vitro. J Bone Miner Metab 30: 119-123, 2012.

30. Tibullo D, Giallongo C, La Cava P, Beretta S, Stagno F, Chiarenza A, Conticello C, Palumbo GA and Di Raimondo F: Effects of imatinib mesylate in osteoblastogenesis. Exp Hematol 37: 461-468, 2009.

31. Heneghan HM, Miller N, Lowery AJ, Sweeney KJ, Newell J and Kerin MJ: Circulating microRNAs as novel minimally invasive biomarkers for breast cancer. Ann Surg 251: 499-505, 2010.

32. Corney DC, Hwang CI, Matoso A, Vogt M, Flesken-Nikitin A, Godwin AK, Kamat AA, Sood AK, Ellenson LH, Hermeking H and Nikitin AY: Frequent downregulation of miR-34 family in human ovarian cancers. Clin Cancer Res 16: 1119-1128, 2010.

33. Tsukamoto Y, Nakada C, Noguchi T, Tanigawa M, Nguyen LT, Uchida T, Hijiya N, Matsuura K, Fujioka T, Seto M and Moriyama M: MicroRNA-375 is downregulated in gastric carcinomas and regulates cell survival by targeting PDK 1 and 14-3-3zeta. Cancer Res 70: 2339-2349, 2010.

34. Chacon-Cabrera A, Fermoselle C, Salmela I, Yelamos J and Barreiro E: MicroRNA expression and protein acetylation pattern in respiratory and limb muscles of Parp- $1^{-/}$and Parp- $2^{-1-}$ mice with lung cancer cachexia. Biochim Biophys Acta 1850: 2530-2543, 2015.

35. Kodahl AR, Lyng MB, Binder H, Cold S, Gravgaard K, Knoop AS and Ditzel HJ: Novel circulating microRNA signature as a potential non-invasive multi-marker test in ER-positive early-stage breast cancer: A case control study. Mol Oncol 8: 874-883, 2014.

36. Zeng RC, Zhang W, Yan XQ, Ye ZQ, Chen ED, Huang DP, Zhang XH and Huang GL: Down-regulation of miRNA-30a in human plasma is a novel marker for breast cancer. Med Oncol 30: 477, 2013 . 
37. Zheng B, Zhu H, Gu D, Pan X2 Qian L, Xue B, Yang D, Zhou J and Shan Y: MiRNA-30a-mediated autophagy inhibition sensitizes renal cell carcinoma cells to sorafenib. Biochem Biophys Res Commun 459: 234-239, 2015.

38. Mao C, Zhang J, Lin S, Jing L, Xiang J, Wang M, Wang B, Xu P, Liu W, Song X and Changjun L: MiRNA-30a inhibits AECs-II apoptosis by blocking mitochondrial fission dependent on Drp-1. J Cell Mol Med 18: 2404-2416, 2014.

39. Yu Y, Yang L, Zhao M, Zhu S, Kang R, Vernon P, Tang D and Cao L: Targeting microRNA-30a-mediated autophagy enhances imatinib activity against human chronic myeloid leukemia cells. Leukemia 26: 1752-1760, 2012.
40. Yu Y, Cao L, Yang L, Kang R, Lotze M and Tang D: microRNA $30 \mathrm{~A}$ promotes autophagy in response to cancer therapy. Autophagy 8: 853-855, 2012

41. Eguchi T, Watanabe K, Hara ES, Ono M, Kuboki T and Calderwood SK: OstemiR: A novel panel of microRNA biomarkers in osteoblastic and osteocytic differentiation from mesencymal stem cells. PLoS One 8: e58796, 2013. 